\title{
Ecological history of Lachlan Nature Reserve, Centennial Park, Sydney, Australia: a palaeoecological approach to conservation
}

\author{
REBECCA HAMILTON* AND DAN PENNY \\ School of Geosciences, Madsen Building F09, The University of Sydney, Sydney, New South Wales 2006, Australia \\ Date submitted: 4 August 2013; Date accepted: 16 February 2014; First published online 8 April 2014
}

\section{SUMMARY}

Reconstructing the environmental history of protected areas permits an empirically-based assessment of the conservation values ascribed to these sites. Ideally, this long-term view can contribute to evidence-based management policy that is both ecologically 'realistic' and pragmatically feasible. Lachlan Nature Reserve, a protected wetland in Centennial Park, Sydney, is claimed to be the final remnant of early and preEuropean swamplands that were once extensive in the area, and the site is thus considered to have indigenous cultural and natural conservation significance. This study uses palynological techniques to reconstruct vegetation communities at the Reserve from the late Holocene to the present in order to assess whether these values adequately reflect the history, character and development of the site. The findings indicate that the modern site flora is a modified Melaleuca quinquenervia low forest assemblage formed in response to aggregated anthropogenic disturbance since colonial settlement. This assemblage replaces an Epacris-dominated heath-swampland community that was extirpated in the mid-20th century. These results emphasize the value of long-term studies in contributing to a realistic management policy that explicitly reflects the normative basis of conservation, and values the influence of past land-uses on contemporary protected ecosystems.

Keypords: conservation management, environmental history, Lachlan Swamp, palaeoecology, palynology, Sydney, wetlands

\section{INTRODUCTION}

Acceptance of the fact that all ecosystems are dynamic, complex, and historically contingent, has led to broad theoretical recognition of the normative nature of conservation practice. This highlights the need to apply value systems in conservation-based decision making to promote meaningful and sustainable policy for protected sites (Barry \& Oelschlaeger 1996; Robertson \& Hull 2001; Moore et al. 2009).

*Correspondence: Rebecca Hamilton e-mail: rebecca.hamilton@ sydney.edu.au
However, this tends not to occur in practice, with conservation goals often founded upon seemingly positivistic (commonly anecdotal) scientific benchmarks, particularly with respect to preservation of 'natural' sites (Wallington et al. 2005; Sutherland et al. 2013). This approach has been applied to the management of Lachlan Nature Reserve, a 1.3 ha protected wetland in Centennial Park, Sydney, which, in the absence of any long-term scientific evidence, is guided by the premise that the contemporary site ecology is representative of the late 18 th and early 19 th century swamplands, offering a link to the early and pre-European environment (Centennial Park and Moore Park Trust 2006, 2012)

There is concern that adopting this approach to management may result in the formulation of narrowly focused and unrealistic objectives that do not account for site-specific land-use legacies and resilience to future change (Davies \& Bunting 2010). Moreover, the reliance on nonevidence-based presumptions of 'naturalness' may prevent managers from considering alternative approaches that may be more cost-effective or more appropriate for the site in terms of sustaining ecological services (Sutherland et al. 2004). In order to strengthen conservation praxis, there is a need for research that demonstrates the inherently normative nature of conservation, thus promoting an approach focused upon pragmatic site-specific decision-making that justifies why the preservation of one version of a landscape is valued over another. In order for this to occur, research is required that tests the validity of conservation objectives commonly applied to protected sites, and which provides robust empirical data that can facilitate informed management policy.

The palaeoecological record provides an empirical framework for assessing past ecosystem dynamics, allowing for the validity of conservation goals to be tested, and, where applicable, re-evaluated (Birks 1996; Foster 2002; Willis \& Birks 2006; Froyd \& Wilis 2008). While such research tends to be poorly used at the science/policy interface (Willis et al. 2007; Davies \& Bunting 2010), these methods have proven successful in dispelling assumptions about the naturalness (or unnaturalness) of particular species and ecosystems, and demonstrate the importance of land-use legacies in shaping ecosystem expression (see for example Oldfield 1970; Foster et al. 2002; Lynch \& Saltonstall 2002; Willis et al. 2004; Brncic et al. 2007; Feurdean \& Willis 2008; Feurdean 2010; Hannon et al. 2010).

There are few instances where palaeoecological approaches have been used to explicitly evaluate and inform conservation 


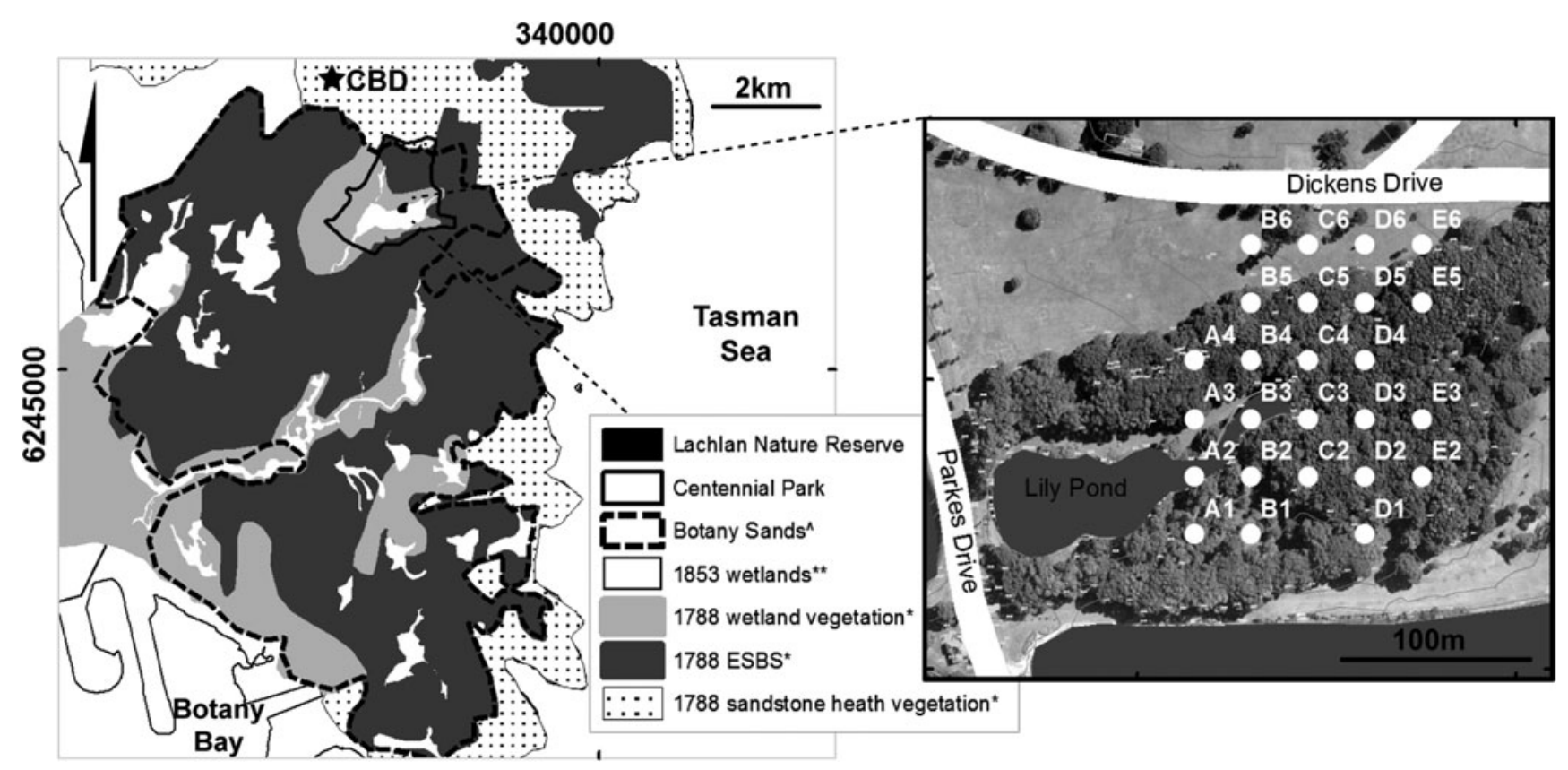

Figure 1 Location of the Lachlan Nature Reserve and Centennial Park. Left: Regional map of the Park in the context of its ^geomorphic context (Public Works Department of NSW 1990), ${ }^{* *}$ mapped 1853 wetlands (State Records of NSW 1853) and *presumed 1788 vegetation units (Benson \& Howell 1994). Right: Location of auger points in the Lachlan Reserve. Projected coordinate system:

GDA_1994_MGA_z56, Transverse Mercator.

policy in the Southern Hemisphere (with exceptions such as Bennett \& Mooney 2003), and fewer still at smallscale sites that have been heavily disturbed by urbanization. Studies assessing the validity of 'naturalness' objectives are, however, of particular relevance to conservation approaches in Australia, which has typically reflected 'new-world' wilderness ideals that emphasize pristine nature, analogous to Cronan's (1996) critique of culturally-constructed wilderness ideals in the USA, despite the long history of intensive human modification of natural systems (Bird et al. 2008).

Effective conservation of remnant ecosystems within urban contexts is important, in part because they are so rare, and because the pressures exerted on these systems, tangible or otherwise, may be diverse and intense, making even well-informed management challenging. The absence of connectivity between disjunct 'patches' represents a particular challenge in urban areas (Godefroid \& Koedam 2003). Rapid global urbanization means disconnected remnant systems, such as the Lachlan Reserve, will become more common in the future (Goddard et al. 2010). Therefore, learning how to properly manage urban ecosystem resilience whilst maximizing ecosystem services in a tightly funded environment is likely to become a preoccupation of urban planners, ecologists and conservationists over coming decades. Here, we provide the missing empirical basis for the management of one such urban conservation area, Lachlan Reserve, within the dense urban core of Sydney. We use palynological techniques to reconstruct the vegetation history of the Reserve and aim to: (1) determine the extent to which the 'natural' values assigned to the site accurately represent its pre-European ecological condition; (2) make an empirical evaluation of the current management goals of the site; and (3) on a broader scale, provide a basis for demonstrating the value of using palaeoecological techniques to conceptualize and assist in the development of realistic evidence-based conservation policy.

\section{Study site}

\section{Hydrogeological setting}

The Lachlan Nature Reserve (Fig. 1) is located within the central precinct of Centennial Park, a 220 ha urban green space c. $4 \mathrm{~km}$ south-east of Sydney's city centre. The Reserve sits at the springhead of what was once a 486-600 ha swampland, the Lachlan Swamps, which drained southwards to Botany Bay in a chain of freshwater wetlands fed by the 18300 ha Botany Sands aquifer (Ashton \& Blackmore 1998; McHugh et al. 1998; Ross et al. 1998).

Site soils are characterized by waterlogged, acidic and skeletal quartz sands, the upper layers of which are discoloured by decayed vegetation. These sediments overlie a Triassic Hawkesbury Sandstone basement, which rises beneath the site causing the aquifer to outcrop at the Reserve springhead (Jankowski \& Beck 2000). This spring and the associated swamplands are of historical importance, providing fresh water and other natural resources to the indigenous Gadi clan and European colonists, and becoming the major supply of fresh water to the colony of Sydney from 1820 to 1859 (Ashton \& Blackmore 1998). 


\section{Site vegetation}

The presumed 'natural' flora of Sydney at European contact (1788) has been mapped and described by Benson and Howell (1990, 1994). Though even semi-natural vegetation remnants are rare within the study region, the pre-European flora of the area is thought to be relatively localized due to the unique geomorphic conditions afforded by the Botany Sands aquifer. The region is presumed to have once supported a swamp-heathland mosaic of Eastern Suburbs Banksia Scrub (ESBS) growing on sand dunes and ridges, interspersed with estuarine and freshwater wetlands in swales and along drainage lines (Fig 1). The ESBS unit, currently listed as an Endangered Ecological Community (NSW [New South Wales] Scientific Committee 2012), predominantly consists of sclerophyllous shrub species (including Banksia aemula R.Br. and B. serrata. L.f.). Natural freshwater swamp units are thought to comprise open-sedge-lands, typified by the presence of Eleocharis sphacelata (R.Br.), Baumea juncea (R.Br) and Persicaria decipiens (R.Br.) (Benson \& Howell 1994), and Melaleuca quinquenervia [(Cav.) S.T.Blake] low-forest units, of which the Lachlan Reserve vegetation is described as a 'surviving example' (Benson \& Howell 1994, p. 711).

The dominant species at the Reserve broadly align with the characteristics of the low-forest freshwater swamp unit described by Benson and Howell (1994). Contemporary canopy vegetation overwhelmingly consists of broad-leaved paperbark (M. quinquenervia), with swamp she-oak (Casuarina glauca Sieber ex Sprengel), swamp mahogany (Eucalyptus robusta Sm.), swamp paperbark (Melaleuca ericifolia Sm.), prickly paperbark (Melaleuca styphelioides Sm.), willow bottlebrush (Callistemon salignus [Sm.] Sweet) and Sydney wattle (Acacia longifolia [Andr.] Willd.) present as minor canopy species. The understorey is dominated by saw sedge (Gahnia sieberiana Kunth) and several fern species, including coral fern (Gleichenia dicarpa R. Br.), hare's foot fern (Davallia solida [G.Forst.] Sw) and harsh ground fern (Hypolepis muelleri N.A.Wakef.), with some basket grass (Lomandra longifolia Labill.) and narrow-leaved palm lily (Cordyline stricta [Sims] Endl.). Several patches of unidentified grass species grow in the vicinity of the site, particularly around the Reserve margins where canopy cover is less dense. The surrounding parkland is vegetated with lawns, avenues and scattered plantings of palms (Phoenix canariensis Chabaud), tropical figs (Ficus sp.), holm oaks (Quercus ilex), Queensland kauri (Agathis robusta [C.Moore ex F.Muell.] Bailey) and hoop and Norfolk Island pines (Araucaria cunninghamii Aiton ex D.Don; Araucaria heterophylla [Salisb.] Franco). There are some patches of wooded grassland around the artificial ponds to the south of the Reserve.

\section{Management approach}

Centennial Park's Plan of Management specifies that the Lachlan Reserve be managed as 'a predominantly natural landscape setting of environmental significance with strong cultural significance' that encourages visitor awareness of its 'sensitive natural and heritage values' (Centennial Park and
Moore Park Trust 2006, p. 50). These values are elaborated upon in the Tree Management Plan, which explains that the Reserve flora, representing a reconstruction of the indigenous swamp vegetation, is significant in that it demonstrates early 20th century efforts to protect the remnant indigenous vegetation of the Park (Context Landscape Design 2002). The prescribed significance of the site is conveyed to visitors by an interpretive boardwalk that runs through the Reserve, aiming to give 'insight into what the area was like before the parkland developed' (Centennial Park and Moore Park Trust 2012).

\section{Historical development of the site}

Use of, and attitudes towards the Lachlan Swamps since European settlement have evolved with changing resource demands and shifting perceptions of the natural environment, and are important in the physical and cultural development of the Reserve. The land-use practices of the indigenous Gadi people prior European contact in 1788, which instigated a catastrophic decline in their population, is poorly understood. However, the wetlands are extremely likely to have provided abundant fresh water and other vital resources tied to the customary and dietary practices of this clan (Dickson 1973; Larcombe 1970).

Following colonization, the Lachlan Swamps were left relatively undisturbed by human activity, having been deemed 'unhealthy' by the then-Governor of the colony (Philip 1982 [1789]). By 1811, problems associated with the grazing of animals in town gardens resulted in 607 ha of land surrounding the Lachlan Swamps set aside as a Common Ground (Doyle 1978). The establishment of several large industrial enterprises within the northern portion of Botany Bay followed, including wool-washing, flour and paper mill operations (The Sydney Gazette and NSW Advertiser 1818; Dow 1974; Marriott 1982; Ashton \& Blackmore 1998). It was throughout this period that the value of the swamplands as a large perennial water supply was recognized. Droughts in the 1820s placed Sydney's existing water supply under substantial pressure (NSW Committee on the Tunnel 1837; Merrick 1998). This resulted in a portion of the Lachlan Swamps being converted into the Lachlan Water Reserve in 1827 , since this natural water supply was 'nearest to town ... and most likely to afford an abundant supply of soft, fresh, water' (NSW Committee on the Tunnel 1837, p. 2). Construction of the water reserve initially involved the installation of a $3.5 \mathrm{~km}$ gravity-fed aqueduct, Busby's Bore, between what is now the western Park entrance and a large reservoir constructed at Hyde Park, Sydney (Public Works Department of NSW 1990). Pressures on this water supply led to further infrastructural works at the swamps, including cutting drains through the swamps (Richards \& NSW Sydney Water Supply Commission 1869), installing steam pumps, and constructing dams (now the location of the parkland ponds) and storage reservoirs (Doyle 1978). The Lachlan Water Reserve contributed to Sydney's water supply until the mid-1880s (Ashton \& Blackmore 1998). 
In 1887, the decommissioned water reserve was converted into Centennial Park in commemoration of the centenary of the colony's founding (Doyle 1978). Park construction, being embedded in the gardenesque school of landscape design (Ashton \& Blackmore 1998), involved the significant reworking of the environment. This included clearing the 'pristine, woody shrub, draining the site... and breaking up the ground' (State Records of NSW 1883-1889). It soon became clear that the botanical design of the park was unsuitable for the free-draining, nutrient-poor soils and climatic conditions of the area (State Records of NSW 1883-1889). Recognizing these limitations, the second Park overseer, Joseph Maiden, adopted a pragmatic approach to management that included planting $M$. quinquenervia wind breaks in 1896 (including the avenues of broad-leaved paperbark that are immediately north of the study area), and preserving 'remnant indigenous flora'(Context Landscape Design 2002, p. 9).

Maintenance of the Park was neglected throughout the first half of the 20th century due to funding and labour shortages associated with World War 1 (Doyle 1978), with the exception of a major tree-planting programme instigated in 1935 (Sydney Morning Herald 1935). In 1964, a Special Committee was established to oversee the improvement of the parklands, including de-silting of the spring-fed ponds and the resumption of tree-planting (Public Works Department of NSW 1990). Responsibility for the park management was handed to a park trust (now the Centennial and Moore Park Trust) in 1983. Management has since been focused on creating a 'designed landscape in an urban context' that must 'continue to expand its role as a conservation park and a refuge for wildlife' (Centennial and Moore Park Trust Act 1983, part 2, section 9, Functions of Trust available at http://www.legislation.nsw.gov.au).

\section{METHODS}

\section{Core extraction}

A hand-auger was used to measure the depth of organic soil and record the stratigraphy at 24 intersections of an $a$ priori $30 \mathrm{~m}$ sampling grid established across 2.7 ha of the site (Fig. 1). The location with the greatest thickness of organic soil, representing the greatest time-depth and providing the best temporal resolution, (core site B2), was sampled by driving a $60 \mathrm{~mm}$ diameter PVC tube into the soil using a sliding hammer and collar device and extracting the core by hand (core LSB2, $63 \mathrm{~cm}$ depth).

\section{Sedimentology}

The volume magnetic susceptibility ( $\kappa \mathrm{vol})$ of the core was measured by passing the whole sample at $2 \mathrm{~cm}$ intervals through a $100 \mathrm{~mm}$ diameter magnetic susceptibility MS2C core-logging sensor attached to a Bartington MS2 meter (Dearing 1999). The core was split in half lengthways, the colour logged (Munsell Colour 1994), and continuous $1 \mathrm{~cm}$ thick subsamples $\left(c .3 .78 \mathrm{~cm}^{3}\right)$ taken. Mineral particle size distributions for each subsample were determined by laser diffraction using a Malvern Mastersizer 2000, following oxidization $\left(30 \% \mathrm{w} / \mathrm{w} \mathrm{H}_{2} \mathrm{O}_{2}\right)$ of 1-1.5 g (wet weight) of material. Soils textures were classified following the United States Department of Agriculture (USDA) classification system (Soil Survey Staff 2010).

\section{Palynology}

Plant microfossils (pollen and spores) were extracted from each subsample following standard procedures (Faegri \& Iversen 1989) and identified and enumerated using Zeiss Axioskop II and Olympus BH-2 light microscopes at $\times 400$ to $\times 1000$ magnification. Pollen and spore taxonomy followed online pollen databases (University of Newcastle 2005; Australian National University 2010) and comparison with reference samples collected from vouchered specimens at the New South Wales Herbarium, Royal Botanical Gardens, Sydney (17 species from 13 families and 15 genera). Following enumeration, microfossil absolute abundance (pollen/g wet sediment) was calculated following Stockmarr (1971) and plotted stratigraphically using the software package $\mathrm{C} 2$ version 1.4 beta (Juggins 2004). The pollen and spore sequence from each sample was classified using CONISS analysis with the program ZONE (Juggins 1992) based on FORTRAN IV programs (Gordon \& Birks 1972), and CONISS FORTRAN 77 (Grimm 1987) (Data counts converted to proportions; dissimilarity coefficient:squared chord distance).

\section{Chronology}

We extracted 12 sediment samples from the core for ${ }^{137} \mathrm{Cs}$ and alpha spectrometry ${ }^{210} \mathrm{~Pb}$ dating between depths of 0 and $51 \mathrm{~cm}$. These were submitted to the Cosmogenic Isotope and Radiochemistry Laboratory, GNS Science, New Zealand, for dating. ${ }^{210} \mathrm{~Pb}$ ages were modelled using the constant initial concentration (CIC) model, following Goldberg (1963), and the constant rate of supply (CRS) model, using CRSModel software developed by Higuera (2012), which calculates sample ages following Binford (1990). One sample was extracted from $60-61 \mathrm{~cm}$ depth for AMS radiocarbon dating to date the base of the core, which was assumed to be beyond the limit of ${ }^{210} \mathrm{~Pb}$ and ${ }^{137} \mathrm{Cs}$ dating. The result was calibrated to calendar years using the IntCAL09 dataset (Reimer et al. 2009) in the program CALIB 6.0 (Stuiver \& Reimer 1986).

Pollen from exotic plants was used to refine the chronology provided by radiometric dating. This approach is particularly useful in the context of Centennial Park because the dates of certain historic plantings in the Lachlan Water Reserve and parkland are accurately known, and their pollen appears in the sedimentary record. The first presence of pollen from Pinus (known to be planted in the vicinity of the site $c .1865$ ), and Ficus (first introduced to the site in 1887-1888 as one 

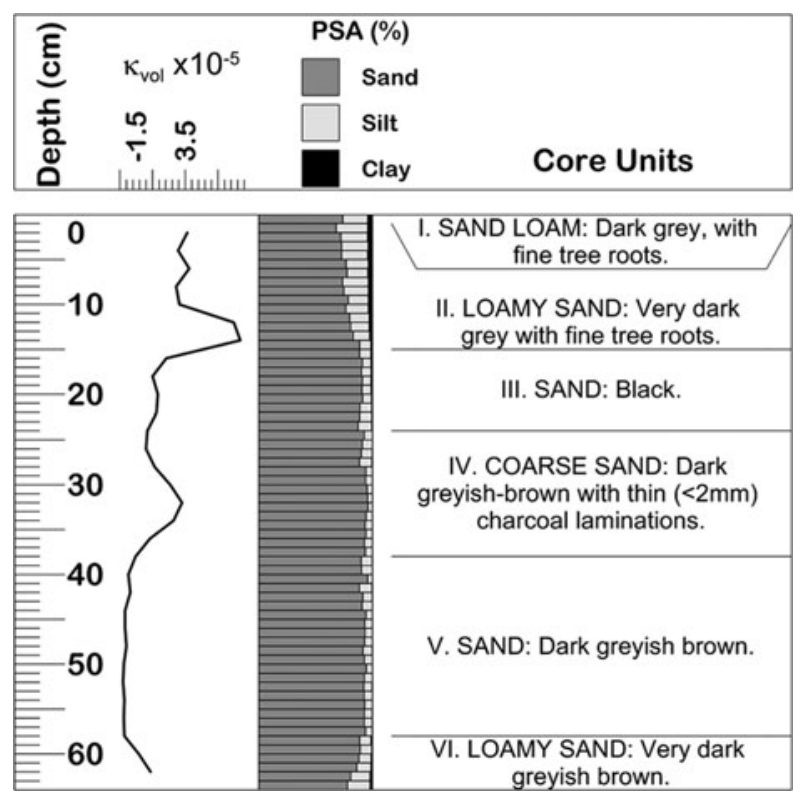

Figure 2 Description and sedimentology of core LSB2.

of the first mass parkland plantings), are considered to be of particular value to the chronology.

\section{RESULTS}

\section{Sedimentology}

Core sediments were comprised of six sand units (I-VI) (Fig. 2). We observed two peaks in Kvol in units III and IV (at 16 and $32 \mathrm{~cm}$ depth), respectively.

\section{Chronology}

Excess lead activity consistently decreased with depth in the core to $20-21 \mathrm{~cm}$, below which negative excess ${ }^{210} \mathrm{~Pb}$ values were measured; core depths beyond $21 \mathrm{~cm}$ were thus beyond the limit of ${ }^{210} \mathrm{~Pb}$ dating. ${ }^{137} \mathrm{Cs}$ is apparent at, and above 18 $19 \mathrm{~cm}$ depth, dating this depth interval at 1955 AD, which is considered to be the earliest appearance of this artificial radioisotope between latitudes of $30-40^{\circ} \mathrm{S}$ (Leslie \& Hancock 2008). There was no clear peak in ${ }^{137} \mathrm{Cs}$ accumulation, which is commonly the case for the Southern Hemisphere (Olley et al. 1990; Table 1).

The sample extracted at $60-61 \mathrm{~cm}$ depth for radiocarbon dating (laboratory number Beta-284319) returned an age of $5450 \pm 40{ }^{14} \mathrm{C}$ yrs before present (BP), calibrated to 4330 4240 calendar yrs BC at 1 SD. Pollen from Pinus appears in the microfossil record at $21-22 \mathrm{~cm}$ depth, and Ficus pollen appears for the first time at $20-21 \mathrm{~cm}$, dating these depths at $c .1865$ and $c .1888$, respectively (Table 1 ).

${ }^{210} \mathrm{~Pb}$ dates modelled using the CIC method appear to correlate better with dates derived from the ${ }^{137} \mathrm{Cs}$ and microfossil markers, and we thus selected them for use in the chronological depth model. This model was established using a third-order polynomial regression of all dated points, which allows for a 'best-fit' for the modelled ages, without being too 'stiff' (too many terms) or 'flexible' (too few terms) (Bennett \& Fuller 2002). Large errors in the age model were apparent above $13 \mathrm{~cm}$ depth due to the recurvature of the polynomial regression, and the ages of these upper sediments (c. 1991 to 2010 ) were based upon the absolute ${ }^{210} \mathrm{~Pb}$ CIC calculations.

The chronological model predicts that the age of the extracted sediments increases with depth. The large radiometrically-measured age gap between the core base ( $60.5 \mathrm{~cm}$ at $c .4889$ calendar yrs BC) and $21.5 \mathrm{~cm}(c .1871 \mathrm{AD})$ implies either extremely low accumulation rates between these time periods (of the order of $0.064 \mathrm{~mm} \mathrm{yr}^{-1}$ ), or an hiatus in the record. The stratigraphic boundary at $24 \mathrm{~cm}$ depth between units III and IV may be associated with one such hiatus in sediment accumulation.

\section{Palynology}

Fifty-four pollen and spore taxa representing 28 families (excluding the morphological classification of fern spores termed 'Monolete' A-C and 'Trilete' A and B) were identified from core LSB2. Major arboreal, herb and fern taxa were plotted stratigraphically (Figs 3 and 4).

Twenty-five pollen and spore types, representing $1.5 \%$ of the total pollen and spore count, could not be identified and were described and photographed. An average of 174 arboreal (woody plant) specimens and 452 pollen and spore specimens were counted per slide, excluding unknown types. The abundance of pollen and spores reduced with depth, with samples below 39-40 cm depth effectively sterile. Vegetation changes are apparent with increasing depth, from an assemblage dominated by $M$. quinquenervia, Poaceae, Cyperaceae and Gleichenia to an assemblage characterized by the presence of by Epacris, Casuarina, Cyperaceae, Restionaceae pollen and Trilete A and B spores, which have been identified as Lycopodium spp. (sensu Macphail 2005, p. 1.3; Large \& Braggins 1991, p. 15). We provide a detailed description here as an appendix (Appendix 1, see supplementary material at Journals.cambridge.org/ENC).

We classified the microfossil data into six sample zones (A-F) based on the outcomes of stratigraphically constrained cluster analysis. The primary division within the data occurs at $20 \mathrm{~cm}$ depth (c. $1896 \mathrm{AD} ; 2.023$ dispersion) followed by a secondary division at $15 \mathrm{~cm}$ (c. 1979 AD; 3.613 dispersion), tertiary at $24 \mathrm{~cm}$ (c. $1770 \mathrm{AD} ; 2.935$ dispersion) and quaternary at $33 \mathrm{~cm}$ (c. $1215 \mathrm{AD} ; 2.447$ dispersion). These divisions represent the zone boundaries (Figs 3 and 4), with zone A representing the deepest, sterile portion of the core $(63-40 \mathrm{~cm})$. This classification appears to correlate well with the three major land-use periods of the Lachlan Swamps: (1) pre-European (pre-1788), represented by microfossil zones $\mathrm{B}$ and $\mathrm{C}$; (2) early-European, including use of the site as the Sydney Common and the Lachlan Water Reserve (1788-1886), represented by microfossil zone D; and (3) 


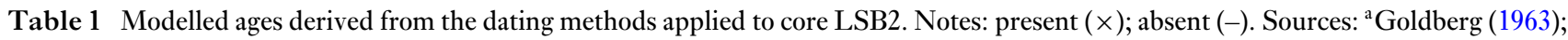
${ }^{\mathrm{b}}$ Binford (1990); ${ }^{\mathrm{c}}$ Leslie and Hancock (2008); ${ }^{\mathrm{d}}$ Stuiver and Reimer (1986); Reimer et al. (2009).

\begin{tabular}{|c|c|c|c|c|c|c|}
\hline $\begin{array}{l}\text { Sample depth } \\
\text { (cm) }\end{array}$ & $\begin{array}{l}{ }^{210} \mathrm{~Pb} \mathrm{CIC} \\
\text { dates }^{a}\end{array}$ & $\begin{array}{l}{ }^{210} \mathrm{~Pb} C R S \text { dates } \\
(95 \% \mathrm{CI})^{b}\end{array}$ & Pinus pollen & Ficus pollen & $\begin{array}{l}{ }^{137} \text { Cs marker } \\
\left(B q k^{-1}\right)^{c}\end{array}$ & $C^{14 d}$ \\
\hline$\overline{0-1}$ & $2007 \mathrm{AD}$ & $2010 \pm 1 \mathrm{AD}$ & $x$ & $x$ & 8.21 & \\
\hline $5-6$ & $2005 \mathrm{AD}$ & $1994 \pm 9 \mathrm{AD}$ & $x$ & $x$ & 6.96 & \\
\hline $10-11$ & $1996 \mathrm{AD}$ & $1969 \pm 15 \mathrm{AD}$ & $x$ & $x$ & 5.61 & \\
\hline $12-13$ & $1991 \mathrm{AD}$ & $1954 \pm 22 \mathrm{AD}$ & $x$ & $x$ & 5.27 & \\
\hline $15-16$ & 1985 AD & $1914 \pm 51 \mathrm{AD}$ & $\times$ & $x$ & 3.01 & \\
\hline $17-18$ & $1958 \mathrm{AD}$ & $1893 \pm 154 \mathrm{AD}$ & $x$ & $x$ & 1.12 & \\
\hline $18-19$ & $1914 \mathrm{AD}$ & & $x$ & $x$ & $0.461955 \mathrm{AD}$ & \\
\hline $19-20$ & $1855 \mathrm{AD}$ & & $x$ & $x$ & & \\
\hline $20-21$ & \multicolumn{2}{|c|}{ negative excess ${ }^{210} \mathrm{~Pb}$} & - & $1888 \mathrm{AD}$ & & \\
\hline $21-22$ & \multicolumn{2}{|c|}{ negative excess ${ }^{210} \mathrm{~Pb}$} & $1865 \mathrm{AD}$ & - & & \\
\hline $30-31$ & \multicolumn{2}{|c|}{ negative excess ${ }^{210} \mathrm{~Pb}$} & - & - & & \\
\hline $40-41$ & \multicolumn{2}{|c|}{ negative excess ${ }^{210} \mathrm{~Pb}$} & - & - & & \\
\hline $50-51$ & \multicolumn{2}{|c|}{ negative excess ${ }^{210} \mathrm{~Pb}$} & - & - & & \\
\hline $60-61$ & \multicolumn{2}{|c|}{ negative excess ${ }^{210} \mathrm{~Pb}$} & - & - & & $4330-4240$ BC \\
\hline
\end{tabular}

Figure 3 Absolute arboreal taxa microfossil abundance (pollen $\mathrm{g} /$ wet sediment) plotted against core depth $(\mathrm{cm})$.

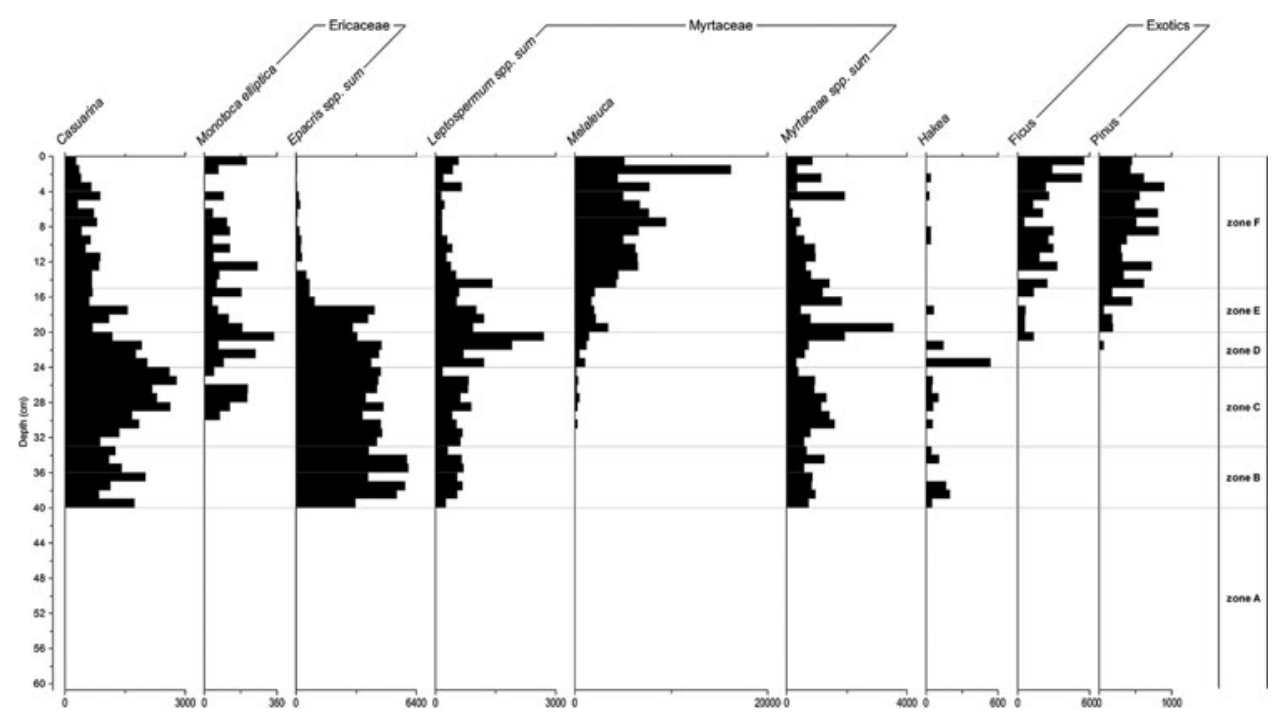

post-establishment of Centennial Park (1887 AD to present), represented by microfossil zones $\mathrm{E}$ and $\mathrm{F}$.

\section{DISCUSSION}

Interpretation of microfossil data in the context of past land use

\section{Pre-European smamplands (pre-1788)}

The composition of the pre-European arboreal pollen assemblage is dominated by the woody heath plant Epacris and the she-oak Casuarina, and may be diagnostic of Sydney's dune heathland communities (Hamilton 1928). When this is considered in conjunction with the dominance of wetland herbs, we conclude that the pre-European community was either a sedge-heath swampland (Beadle 1981) or, if the site was immediately proximal to an elevated dune (D'Costa \& Kershaw 1997), a sedge-swamp heathland mosaic. This latter interpretation is plausible given the illustration of ridge- tops punctuated with waterlogged depressions on mid-19th century maps of the Botany Sands region (State Records of NSW 1845, 1847, 1853). Additionally, comparison of the existing site location with georeferenced historical maps of the site indicates that the study area is likely to have been situated along the northern boundary of the water reserve, adjacent to 'sandy ground covered with brushwood' (State Records of NSW 1845).

\section{Early European Smamplands (c. 1770 AD-1887 AD)}

Zone $\mathrm{D}$ represents the vegetation assemblage growing within the vicinity of the site during the use of the swampland as Sydney's Common Ground and Water Reserve. There is no dramatic change in the dominant heath-swampland assemblage at the interface of zones $\mathrm{C}$ and $\mathrm{D}$. The relative stability of the flora across this boundary indicates that, if there is an hiatus in sedimentation at this point, either the uppermost sediments of Units C and D have been mixed, 
Figure 4 Absolute herb and fern taxa microfossil abundance (pollen $\mathrm{g} /$ wet sediment) plotted against core depth $(\mathrm{cm})$.

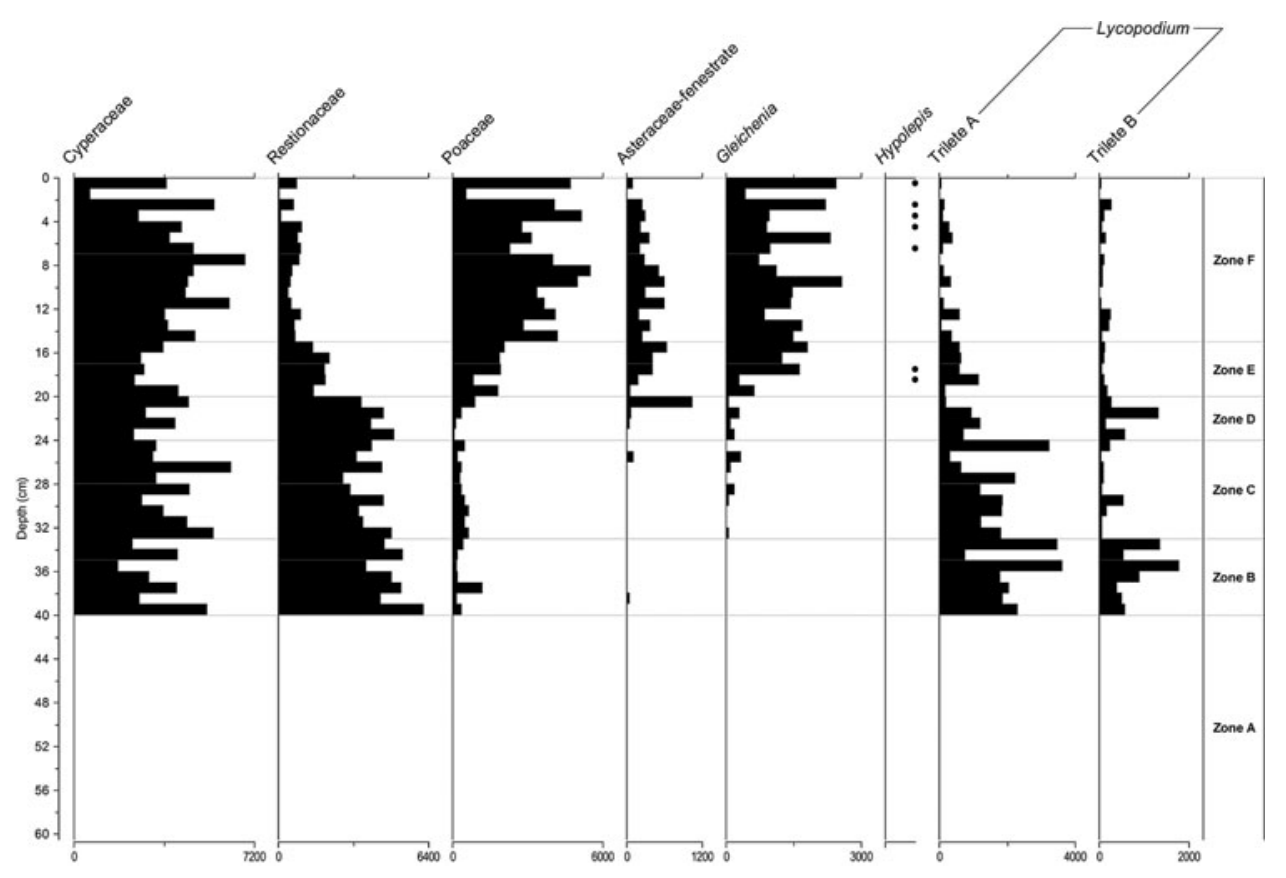

or there were limited changes to the vegetation across the putative discontinuity. Alternatively, the onset of European arrival increased rates of sediment delivery to and storage in the swamp (potentially associated with the tree felling and soil compaction which occurred after the establishment of the Common in 1811). This is a common characteristic of early European disturbance to the landscape within south-eastern Australia (Gale \& Haworth 2002).

Several changes to the palynological assemblage indicate increasing levels of anthropogenic manipulation of the natural environment throughout this period, and are well-aligned with written records of the site. This includes evidence of (1) livestock disturbance (Richards \& NSW Sydney Water Supply Commission 1869); (2) drying and reduced filtration of the swamp surface due to over extraction and sediment compaction (Richards \& NSW Sydney Water Supply Commission 1869); (3) timber collection at the site prior to the construction of the parkland (Richards \& NSW Sydney Water Supply Commission 1869; Lynch \& Larcombe 1959); and (4) land clearance in preparation for the Park (State Records of NSW 1883-1889). Some floristic changes are also suggestive of soil nutrient loading, potentially from the dumping of residential waste products and industrial effluents at the water reserve (Johnson et al. 2003). Though anthropogenic disturbances at the site modified the swampland vegetation to a degree, the site still appears to have broadly supported a swamp-heathland community in 1885 , comparable to the pre-European flora.

\section{The Centennial Park smamplands and Lachlan Nature Reserve (1887 to the present)}

Major changes to the site are observable in the sedimentary record in the century after the establishment of Centennial Park in 1888. Most notably, there is a marked drop in the abundance of Epacris in $c .1954$ and a dramatic expansion of $M$. quinquenervia to the present day, which occurs in two distinct steps at $c .1896$ and $c .1979$. The first of these appears to be correlated with Maiden's planting of windbreak belts around the Lily Pond between 1895 and 1910 (Ashton \& Blackmore 1998). The second, more dramatic rise may be related to the deliberate planting out of the site with $M$. quinquenervia. Increased canopy shading suppresses heath vegetation (der Moral et al. 1978) and therefore the expansion of this canopy species may be responsible for the further reduction in the abundance of Epacris sp. from the mid-1970s to the present day (our 2010 estimate of $M$. quinquenervia canopy cover across the site was $>90 \%$ ).

Changes to the site hydrology, soils and ecosystem function associated with the expansion of $M$. quinquenervia, site fragmentation and pressures induced from surrounding urban land uses are likely to have caused the distinct vegetation shifts noted in the upper layers of the record. Key changes include the near-complete demise of the original swamp heath species that are adapted to nutrient-poor soils (Lamont 1972), the depletion of Restionaceae, a family highly prone to competition-induced local extinction following the influx of nutrients (Meney \& Pate 1999), and the colonization of the Lachlan Swamp Reserve with hardy pollutant- and nutrienttolerant plants (including Cyperaceae, probably Gahnia sieberiana [Coates 2003], and Gleichenia dicarpa [Clarkson et al. 2004]). The combination of these vegetation changes has caused the pre-parkland swamp-heathland communities to change to a novel Melaleuca quinquenervia low-forest unit (Benson \& Howell 1994).

\section{Implications for broader conservation practice}

The long-term vegetation reconstruction of the Lachlan Swamp Reserve indicates that the modern site flora is a modified late 20th century assemblage that has formed in 
response to the aggregated anthropogenic disturbance of the site since colonial settlement. This scientific view of the site is at odds with the image of the landscape presented to public and enshrined in Park policy. The existing conservation values assigned to the Reserve have rather been demonstrated to be a product of contemporary social constructions of 'nature' and indigenous culture.

These findings highlight that the natural and cultural histories of the Lachlan Reserve are closely, perhaps inseparably intertwined, and the cultural influences on the site cannot be viewed as an external and undesirable set of perturbations. Our data have shown these to be intrinsic to the site's present status and conservation value. Indeed, the high historical value of the Lachlan Swamps and associated springhead, as well as the recreational and aesthetic ecosystem services that it currently provides to Park users, are arguably as worthy of conservation as any ecological values that the site may possess. This aspect of the Reserve, in combination with the fact that restoration of the site to 'natural' preEuropean heathland conditions would be impractical, costly and probably unsustainable in the long term, makes a strong case for the re-evaluation of the contemporary conservation policy. We argue that, in order to realistically express the conservation value of the site, its cultural and social value should be highlighted in the context of its environmental history and contemporary usage, and explicitly incorporated into its management and interpretation.

On a broader scale, the disjunction between the actual and the perceived naturalness of Lachlan Reserve demonstrates, on a practical level, the value of long-term studies in contributing to the management of protected areas. In this, as with other cases around the world, conservation practice is shown to be as much a product of culture as it is of science, and continually evolving to reflect the dominant landscape preference of the time (Caldwell 1990). Applying a palaeoecological perspective highlights that conservation practice may be informed by anecdote and myth rather than rigorous empirical data (Willis \& Birks 2006). It also provides an important starting point for scientificallyinformed, evidence-based decision making that can assist managers to determine which iteration of an historic landscape is most valued for conservation (Sutherland et al. 2004; Willis \& Birks 2006; Davies \& Bunting 2010).

The need for informed normative goal setting in conservation practice is of increasing relevance within context of the Anthropocene, particularly in the world's burgeoning urban environments, where most humans now live. The recognition that humans, non-humans and the physical world are interdependent (Folke et al. 2010) is of particular importance to the management of the ever-increasing number of fragmented protected sites (such as the Lachlan Reserve) because these are typically most influenced by land-use legacies, often have important contemporary cultural, social and recreational value, and are subject to high alternative landuse pressures.

\section{ACKNOWLEDGEMENTS}

We thank the reviewers of this manuscript, whose insights and comments substantially improved the quality of this paper. We would also like to acknowledge the Centennial Park and Moore Park Trust staff, in particular M. Secombe, D. Caple and L. Thomas, for allowing us to conduct the necessary fieldwork at the Lachlan Nature Reserve, and D. Dixon, who provided access to and assistance with the collection of reference pollen and spore samples from the NSW Herbarium Collection at the Royal Botanical Gardens, Sydney. We also thank S. Gale, D. Harris, K. Davies and T. Savage from the USYD School of Geosciences, and A. Wilson and M. Hendrickson from the Archaeological Computing Laboratory at USYD, for their assistance with the collection and analysis of the field and laboratory data for this study.

\section{Supplementary material}

To view supplementary material for this article, please visit Journals.cambridge.org/ENC

\section{References}

Ashton, P. \& Blackmore, K. (1998) Centennial Park: A History. Sydney, Australia: UNSW Press.

Australian National University (2010) Australasian pollen and spore atlas [www document]. URL http://apsa.anu.edu.au

Barry, D. \& Oelschlaeger, M. (1996) A science for survival: values and conservation biology. Conservation Biology 10(3): 905-911.

Beadle, N.C.W. (1981) The Vegetation of Australia. Cambridge, UK: Cambridge University Press.

Bennett, K.D. \& Fuller, J.L. (2002) Determining the age of the midHolocene Tsuga cana densis (hemlock) decline, eastern North America. The Holocene 12(4): 421-429.

Bennett, P. \& Mooney, S.D. (2003) A palynological reconstruction of pre-European riparian vegetation at Wollimbi, New South Wales and its application to stream bank management. Ecological Management E Restoration 4(s1): s69-s78.

Benson, D. \& Howell, J. (1990) Taken for Granted: The Bushland of Sydney and its Suburbs. Sydney, Australia: Kangaroo Press.

Benson, D. \& Howell, J. (1994) The natural vegetation of the Sydney 1:100 000 map sheet. Cunninghamia 3(4): 677-787.

Binford, M.W. (1990) Calculation and uncertainty analysis of $210 \mathrm{~Pb}$ dates for PIRLA project lake sediment cores. Fournal of Paleolimnology 3(3): 253-267.

Bird, R.B., Bird, D.W., Codding, B.F., Parker, C.H. \& Jones, J.H. (2008) The 'fire stick farming' hypothesis: Australian aboriginal foraging strategies, biodiversity, and anthropogenic fire mosaics Proceedings of the National Academy of Sciences USA 105(39): 14796-14801.

Birks, H.J.B. (1996) Contributions of Quaternary palaeoecology to nature conservation. Fournal of Vegetation Science 7(1): 89-98.

Brncic, T.M., Willis, K.J., Harris, D.J. \& Washington, R. (2007) Culture or climate? The relative influences of past processes on the composition of the lowland Congo rainforest. Philosophical Transactions of the Royal Society of London B Biological Sciences 362(1478): 229-242. 
Caldwell, L.K. (1990) Landscape, law and public policy: conditions for an ecological perspective. Landscape Ecology 5(1): 3-8.

Centennial Park and Moore Park Trust (2006) Centennial Parklands Plan of Management 2006-2016. Report. Centennial Park and Moore Park Trust, Paddington, Australia.

Centennial Park and Moore Park Trust (2012) Self-guided walks: Centennial Parklands [www document]. URL http://www.centennialparklands.com.au/activities/tours/ self_guided_walks

Clarkson, B.R., Schipper, L.A. \& Lehmann, A. (2004) Vegetation and peat characteristics in the development of lowland restiad peat bogs, North Island, New Zealand. Wetlands 24(1): 133-151.

Coates, T.D. (2003) The effect of concentrated smoke products on the restoration of highly disturbed mineral sands in southeast Victoria. Ecological Management and Restoration 4(2): 133139.

Context Landscape Design (2002) Tree Master Plan: Volume 1. Report no. 98.671. Paddington, Australia: Centennial Park and Moore Park Trust.

Cronan, W. (1996) The trouble with wilderness; or, getting back to the wrong nature. In: Uncommon Ground: Rethinking the Human Place in Nature. ed. W. Cronon, pp. 96-190. New York, NY, USA: W.W. Norton \& Company Ltd.

D’Costa, D. \& Kershaw, P. (1997) An expanded recent pollen database from south-eastern Australia and its potential for refinement of palaeoclimate estimates. Australian fournal of Botany 45(3): 583-605.

Davies, A.L. \& Bunting, M.J. (2010) Applications of palaeoecology in conservation. The Open Ecology fournal 3: 54-67.

Dearing, J. (1999) Environmental Magnetic Susceptibility: Using the Bartington MS2 System. Kenilworth, UK: Chi Publishing.

der Moral, R., Willis, R.J. \& Aston, D.H. (1978) Suppression of coastal heath vegetation by Eucalyptus baxteri. Australian Fournal of Botany 26(2): 203-219.

Dickson (1973) Aboriginal Pre-History of Botany Bay. In: The Botany Bay Project: A Handbook of the Botany Bay Region: Some Preliminary Papers. ed. D.J. Anderson, pp. 40-50. Sydney, Australia: The Botany Bay Project Committee.

Dow, G.M. (1974) Samuel Terry: The Botany Bay Rothschild. Sydney, Australia: Sydney University Press.

Doyle, F. (1978) Centennial Park: A Lecture Given to the Society in April 1978. Randwick, Sydney, Australia: Randwick District Historical Society.

Faegri, K. \& Iversen, J. (1989) Textbook of Pollen Analysis. Chichester, UK: John Wiley \& Sons.

Feurdean, A. (2010) Forest conservation in a changing world: natural or cultural? Example from the Western Carpathians forests, Romania. Studia Universitatis Babes-Bolyai, Geologia 55(1): 4548.

Feurdean, A. \& Willis, K.J. (2008) The usefulness of a long-term perspective in assessing current forest conservation management in the Apuseni Natural Park, Romania. Forest Ecology and Management 256(3): 421-430.

Folke, C., Carpenter, S.R., Walker, B., Scheffer, M., Chapin, T. \& Rockström, J. (2010) Resilience thinking: integrating resilience, adaptability and transformability. Ecology and Society 15(4): 20 [www document]. URL http://www.ecologyandsociety.org/vol15/iss4/art20/

Foster, D.R. (2002) Conservation issues and approaches for dynamic cultural landscapes. Fournal of Biogeography 29(10/11): 15331535 .
Foster, D.R., Hall, B., Barry, S., Clayden, S. \& Parshall, T. (2002) Cultural, environmental and historical controls of vegetation patterns and the modern conservation setting on the island of Martha's Vineyard, USA. Fournal of Biogeography 29(10/11): 1381-1400.

Froyd, C.A. \& Wilis, K.J. (2008) Emerging issues in biodiversity and conservation management: the need for a palaeoecological perspective. Quaternary Science Reviems 27(17-18): 1723-1732.

Gale, S.J. \& Haworth, R.J. (2002) Beyond the limits of location: human environmental disturbance prior to official European contact in early colonial Australia. Archaeology in Oceania 37(3): 123-136.

Goddard, M.A., Dougill, A.J. \& Benton, T.G. (2010) Scaling up from gardens: biodiversity conservation in urban environments. TRENDS in Ecology and Evolution 25(2): 90-98.

Godefroid, S. \& Koedam, N. (2003) How important are large vs. small forest remnants for the conservation of the woodland flora in an urban context? Global Ecology and Biogeography 12: 287-298.

Goldberg, E.D. (1963) Geochronology with 210Pb. In: Radioactive Dating, Proceedings of a Symposium on Radioactive Dating, ed. International Atomic Energy Agency pp. 121-131. Vienna, Austria: International Atomic Energy Agency.

Gordon, A.D. \& Birks, H.J.B. (1972) Numerical methods in Quaternary palaeoecology 1. Zonation of pollen diagrams. Nem Phytologist 71(5): 961-979.

Grimm, E.C. (1987) CONISS: A FORTRAN 77 program for stratigraphically constrained cluster analysis by the method of incremental sum of squares. Computers and Geosciences 13(1): 1335.

Hamilton, H.W. (1928) The distribution of vegetation in the Sydney region. The Australian Geographer 1(1): 43-49.

Hannon, G.E., Niklasson, M., Brunet, J.Â., Eliasson, P. \& Lindbladh, M. (2010) How long has the 'hotspot' been 'hot'? Past stand-scale structures at Siggaboda nature reserve in southern Sweden. Biodiversity and Conservation 19(8): 2167-2187.

Higuera, P.E. (2012) CRSModel: a program for chronology development from lead-210 measurements in continuous sediment records [www document]. URL http://code.google.com/p/crsmodel/

Jankowski, J. \& Beck, P. (2000) Aquifer heterogenity: hydrogeological and hydrogeochemical properties of the Botany Sands aquifer and their impact on contaminant transport. Australian Fournal of Earth Sciences 47(1): 45-64.

Johnson, S.G., Slavich, P.G. \& Hirst, P. (2003) Alteration of groundwater and sediment geochemistry in a sulfidic backswamp due to Melaleuca quinquenervia encroachment. Australian fournal of Soil Research 41(7): 1343-1367.

Juggins, S. (1992) ZONE Version 1.2. University of Newcastle, Newcastle upon Tyne, UK.

Juggins, S. (2004) C2 Data Analysis. Version 1.4 Beta (build 3.2). University of Newcastle, Newcastle upon Tyne, UK.

Lamont, B. (1972) The effect of soil nutrients of the production of proteoid roots by Hakea species. Australian Fournal of Botany 20(1): 27-40.

Larcombe, F.A. (1970) The History of Botany Bay 1788-1970. Sydney, Australia: Halstead Press.

Large, M.F. \& Braggins, J.E. (1991) Spore Atlas of Nem Zealand Ferns and Fern Allies. Wellington, New Zealand: SIR Publishing.

Leslie, C. \& Hancock, G.J. (2008) Estimating the date corresponding to the horizon of the first detection of $137 \mathrm{Cs}$ and $239+240 \mathrm{Pu}$ in sediment cores. Fournal of Environmental Radioactivity 99(3): 483490. 
Lynch, E.A. \& Saltonstall, K. (2002) Paleoecological and genetic analysis provide evidence for recent colonization of native Phragmites australis populations in a Lake Superior wetland. Wetlands 22(4): 637-646.

Lynch, W.B. \& Larcombe, F.A. (1959) Randwick 1859-1959. Sydney, Australia: Oswald Ziegler Publications.

Macphail, M.K. (2005) Pollen Analysis of Soil Samples, 109_ 113 George Street, Parramatta. Palynological report prepared 27 November 2005. Casey \& Lowe Pty Ltd, Marrickville, Australia [www document]. URL http://www.caseyandlowe.com.au/ rept109george.htm

Marriott, E.W. (1982) Thomas West of Barcom Glen: His Life, Times and Family. Bowral, Australia: Barcom Press.

McHugh, G.R., Cohen, D.R., Dixon, E., Mooney, S.D. \& Rutherford, N.F. (1998) The Geochemistry of Pond Sediments in Centennial Park, Botany Basin. Springwood, Australia In: Environmental Geology of the Botany Basin, ed. G.H. McNally \& J. Jankowski, pp. 58-69. Springwood, Australia: EEHSG of the Geological Society of Australia and Conference Publications.

Meney, K.A. \& Pate, J.S. (1999) Australian Rushes: Biology, Identification and Conservation of Restionaceae and Allied Families. Perth, Australia: University of WA Press.

Merrick, N.P. (1998) Glimpses of history: the evolution of groundwater levels and usage in the Botany Basin. In: Environmental Geology of the Botany Basin, ed. G.H. McNally \& J. Jankowski, pp. 230-242. Springwood, Australia: EEHSG of the Geological Society of Australia and Conference Publications.

Moore, S.A., Wallington, T.J., Hobbs, R.J., Ehrlich, P.R., Holling, C.S., Levin, S., Lindenmayer, D., Pahl-Wostl, C., Possingham, H., Turner, M.G. \& Westoby, M. (2009) Diversity in current ecological thinking: implications for environmental management. Environmental Management 43(1): 17-27.

Munsell Colour (1994) Munsell Soil Colour Charts. New Windsor, New York, USA: Gretag Macbeth.

NSW Committee on the Tunnel (1837) Tunnel: minutes of evidence taken before the Committee on the Tunnel for conducting water into the town of Sydney. Report. Government Printer, Sydney, Australia: $15 \mathrm{pp}$.

NSW Scientific Committee (2012) Eastern Suburbs banksia scrub in the Sydney Basin Bioregion: endangered ecological community listing. Report. NSW Office of Environment and Heritage, Sydney, Australia

Oldfield, F. (1970) The ecological history of Blelham Bog National Nature Reserve. In: Studies in the Vegetational History of the British Isles, ed. D. Walker \& R.G. West, pp. 141-157. Cambridge, UK: Cambridge University Press.

Olley, J., Murray, A.S., Wallbrink, P.J., Caitecheon, G. \& Stanton, R. (1990) The use of fallout radionuclides as chronometers. In: Proceedings of the Quaternary Dating Workshop 1990, ed. R. Gillespie, pp. 51-55. Canberra, Australia: Department of Biogeography and Geomorphology, Australian National University.

Philip, A. (1982 [1789]) The Voyage of Governor Phillip to Botany Bay with an Account of the Establishment of the Colonies of Port Fackson and Norfolk Island. Melbourne, Australia: Hutchinson Group.

Public Works Department of NSW (1990) Centennial Park study. PWD Report no. 90036. Public Works Department, Sydney, Australia.

Reimer, P.J., Baillie, M.G.L., Bard, E., Bayliss, A., Beck, J.W., Blackwell, P.G., Ramsey, C.B., Buck, C.E., Burr, G.S., Edwards,
R.L., Friedrich, M., Grootes, P.M., Guilderson, T.P., Hajdas, I., Heaton, T.J., Hogg, A.G., Hughen, K.A., Kaiser, K.F., Kromer, B., McCormac, F.G., Manning, S.W., Reimer, R.W., Richards, D.A., Southon, J.R., Talamo, S., Turney, C.S.M., van der Plicht, J. \& Weyhenmeyer, C.E. (2009) IntCal09 and Marine09 radiocarbon age calibration curves, $0-50,000$ years CAL BP. Radiocarbon 51(4): 1111-1150.

Richards, T. \& NSW Sydney Water Supply Commission (1869) Sydney Water Supply: Report of the Commission appointed to inquire into the supply of water to Sydney and suburbs. Government Printer, Sydney, Australia.

Robertson, D.P. \& Hull, B. (2001) Beyond biology: toward a more public ecology for conservation. Conservation Biology 15(4): 970979.

Ross, J.B., Gibbs, B., Bennett, M. \& Smolenski, B. (1998) Examples of effective groundwater remediation of contaminated sites in the Botany Basin. In: Environmental Geology of the Botany Basin, ed. G.H. McNally \& J. Jankowski, pp. 111-120. Springwood, Australia: EHSG of the Geological Society of Australia and Conference Publications.

Soil Survey Staff (2010) Keys to Soil Taxonomy. Washington, DC, USA: United States Department of Agriculture (USDA), Natural Resources Conservation Service (NRCS).

State Records of NSW (1845) Moir: Sketch Lachlan Swamp and Water Reserve (Centennial Park). SG Map L.1.259. State Records of New South Wales 3335. Penrith, Australia.

State Records of NSW (1847) W.W. Dark: Copy of S.1292 of suburbs of Sydney-Darlinghurst towards Waverly, including Lachlan Water Reserve now Centennial Park. SG Map S.1.1292. State Records of NSW 5687. Penrith, Australia.

State Records of NSW (1853) J.S. Adam: Survey of part of country between Old South Head Road-Darlinghurst-Bondi to Botany Bay and Cook's River. Forwarded to Colonial Secretary by Acting Deputy Surveyor General John Thompson by Letter No.53/396, 20 Aug 1853. SG Map S.4.1292. State Records of NSW 5690. Penrith, Australia.

State Records of NSW (1883-1889) Diary of James Jones, the Head Gardener of the Botanic Gardens. NRS 13132. State Records of New South Wales 2/8588. Penrith, Australia.

Stockmarr, J. (1971) Tablets with spores used in absolute pollen analysis. Pollen et Spores 13(1): 615-621.

Stuiver, M. \& Reimer, P. (1986) A computer program for radiocarbon age calibration. Radiocarbon 28(2B): 1022-1030.

Sutherland, W.J., Bardsley, S., Clout, M., Depledge, M.H., Dicks, L.V., Fellman, L., Fleishman, E., Gibbons, D.W., Keim, B., Lickorish, F., Margerison, C., Monk, K.A., Norris, K., Peck, L.S., Prior, S.V., Scharlemann, J.P., Spalding, M.D. \& Watkinson, A.R. (2013) A horizon scan of global conservation issues for 2013. Trends in Ecology and Evolution 28(1): 16-22.

Sutherland, W.J., Pullin, A.S., Dolman, P.M. \& Knight, T.M. (2004) The need for evidence-based conservation. Trends in Ecology and Evolution 19(6): 305-308.

Sydney Morning Herald (1935) Centennial Park: extensive tree-plant scheme. In: The Sydney Morning Herald. 29 August 1935, p. 10. Sydney, Australia: Fairfax Media.

The Sydney Gazette and NSW Advertiser (1818) Paper manufactory. In: The Sydney Gazette and New South Wales Advertiser. 2 May 1818, p. 4. Sydney, Australia: G. Howe.

University of Newcastle (2005) The Newcastle pollen collection [www document]. URL http://apsa.anu.edu.au 
Wallington, T.J., Hobbs, R.J. \& Moore, S.A. (2005) Implications of current ecological thinking for biodiversity conservation: a review of the salient issues. Ecology and Society 10 (1): 15 .

Willis, K.J. \& Birks, H.J. (2006) What is natural? The need for a longterm perspective in biodiversity conservation. Science 314(5803): $1261-1265$.
Willis, K.J., Araujo, M.B., Bennerr, K.D., Figueroa-Rangel, B., Froyd, C.A. \& Myers, N. (2007) How can a knowledge of the past help conserve the future? Biodiversity, conservation and the relevance of long-term ecological studies. Philosophical Transactions of Royal Society B 362(1478): 175-178.

Willis, K.J., Gillson, L. \& Brncic, T.M. (2004) How 'virgin' is virgin rainforest? Science 304(5669): 402-403. 